\title{
Modern technologies of the removal of nutrients from sewage and the study of microbiological processes in their application
}

\author{
Elena Gogina ${ }^{1}$, Olga Ruzhitskaya $^{2}$ \\ ${ }^{1}$ Moscow State University of Civil Engineering, Yaroslavskoe shosse, 26, Moscow, 129337, Russia \\ ${ }^{2}$ Peoples' Friendship University of Russia (RUDN), Department of construction and architecture, 6 \\ Miklukho-Maklaya St., Moscow, 117198, Russia
}

\begin{abstract}
This work presents the results of microbiological studies aimed at exploring the deeper removal of ammonium nitrogen and phosphates from domestic wastewater. This document presents the results of the study of heterotrophic removal of ammonium nitrogen from wastewater for the single sludge technological scheme of biological wastewater treatment. We offered the method of deep wastewater treatment using feed material reinforced by steel wire. Steel wire in the feed material has a significant impact on the quantity and diversity of species composition of protozoans in activated sludge, and leads to intensive development of Chlorella sp. as well.
\end{abstract}

\section{Introduction}

In the past 20 years the problem of nutrient removal has gained special meaning. Due to stiffening of standards on wastewater discharge into water bodies, which took place in the early 90's in the Russian Federation, applicable methods of wastewater treatment from nitrogen and phosphorus compounds as well as technological schemes are being regularly developed. Problems regarding implementation of developed wastewater treatment methods are the following: most sewage treatment facilities in industrial enterprises, cities and settlements in the Russian Federation were built before the 90's and nowadays they require reconstruction. The sum that is needed for investment in reconstruction of sewage treatment facilities is significant, but the options are limited. That is why this question comes up again regarding the need of sewage treatment facilities reconstruction with minimal financial investments, making maximum use of existing capacities and obtaining the required standard quality of wastewater treatment.

In recent years considerable experience was gained that allows to use new methods of sewage treatment facilities reconstruction which is based on modern scientific and technological achievements.

Current constructions at sewage treatment facilities allow to solve problems of wastewater treatment intensification while introducing modern technologies and make it possible to maintain the quality of treated wastewater that meets modern requirements with minimal capital investments. The quality of wastewater treatment is based not only on the 
results of sanitary and chemical analyses, but also on the deep study of microbiological bases of processes that occur during biological treatment.

\section{The technology of deep removal of ammonium nitrogen}

In the basic technological scheme of wastewater treatment from nitrogen compounds (the Russian Federation patent No. 2185338 dated July 20, 2002 "The method of deep biological wastewater treatment from nitrogen ammonium salts") the goal is achieved by the process of biological purification of wastewater in the aero tank which is divided into four successively alternate anoxic and aerobic zones where wastewater and activated sludge fed into in a certain percentage. Then the sludge mixture is sent to the secondary settling tank for separation.

Variation of different parameters is possible depending on the quality requirements to treatment and local conditions based on developed main scheme. For example, it is possible to change treatment time of sewer liquid, the number of zones and time when sewer liquid stays in them.

The offered method has been successfully applied for reconstruction of sewage treatment facilities in the Moscow region, since it does not require construction of special facilities and can be applied using existing aero tanks after their simple reconstruction. The quality of the wastewater treatment is fully consistent with the normative data.

\section{The study of microbiological process of removing ammonium nitrogen}

During the study of microbiological process of removing ammonium nitrogen from wastewater by using single sludge denitrification/nitrification method, first of all attention was paid to:

- reasons for total nitrogen decrease;

- $\quad$ Effect of duration of time when sludge mixture stays in a reactor on qualitative and quantitative composition of the activated sludge;

- microbiological conditions for optimization of reactor operation.

According to the study methods the following was accomplished: sampling of activated sludge from all areas of the reactor followed by the bacterial suspension sowing with the purpose of nitrification activity counting and detection, the exploration in light microscope of live activated sludge and studying of fixed activated sludge using light and scanning electron microscopes.

In addition to ammonium nitrogen domestic wastewater usually contain a quite large amount of organic nitrogen in the forms of proteins, peptides, amino acids. In the process of biological wastewater treatment ammonium nitrogen is oxidized, and value of organic nitrogen remains unchanged, or slightly decreases. Then wastewater flows into water bodies, where protein component of the total nitrogen is destroyed by proteolytic enzymes, i.e. ammonification reactions occur until formation of nitrogen ammonium salts. Secondary pollution of water takes place as a result of dumping a large amount of organic nitrogen into a waterbody. In order to reduce pollution the amount of organic nitrogen in sewage treatment facilities should be reduced.

Using single sludge denitrification/nitrification method for reactor operation allows to achieve partial or total organic nitrogen removal. This happens only when retention time of sludge mixture in the reactor is 8 and 12 hours. The results of the studies of microbiological basis of ammonium nitrogen oxidation and limits of transition to organic nitrogen oxidation are presented for the purpose of better understanding of the process. 
Studies have shown that with a sufficient amount of ammonium nitrogen in wastewater the percentage of organic nitrogen remains unchanged during the treatment process. Complete wastewater treatment from ammonium nitrogen leads to decrease of organic part and increase of ammonium, i.e. ammonification reaction is observed. As a result ammonium deficiency leads to consumption of organic nitrogen by bacteria. This reaction requires using proteolytic enzymes which cause hydrolysis of protein, peptide etc. However, it is known that, nitrification reactions are typical for nitrifying bacteria, that are autotrophs and not able to produce proteolytic enzymes for organic compounds destruction. In other words insufficient ammonium nutrition of nitrifying bacteria leads to inclusion of heterotrophic bacteria which are able to produce proteolysis, into the food chain. It should also be noted that proteolytic enzymes are the poison for a living prokaryotic cell, i.e. for autotrophic nitrifying bacteria.

Therefore, in this study we need to find out the following: whether the number of nitrifies is decreasing as a result of ammonium deficiency and their death promotes production of proteolysis, which destroy proteins and peptides, or in addition to the known autotrophic nitrifying bacteria the process of nitrification is carried out by heterotrophs, which use ammonium as well as organic component of total nitrogen for nutrition, but suppressing the activity of autotrophic nitrifies.

The first hypothesis can be rejected immediately, because according to this version the death of nitrifies will reduce the activity of nitrification process during returning of the activated sludge to the first zone of reactor due to low growth rate of these bacteria. Therefore, the treatment process is carried out according to the second hypothesis. To prove this version microbiological plating was carried out with counting of bacterial colonies and determination of their activity to nitrification of heterotrophs and autotrophs.

Microbiological activity analysis in the reactor is based on the total number of bacteria in a sample of each zone of the reactor and defined by the accumulation of nitrites and nitrification ability of bacterial community.

Studies have shown that during determining of the nitrifying activity in the reactor community due to the development of autotrophic nitrifies it was revealed that this physiological group is presented by a very small number. Practically there was no accumulation of nitrites as well as nitrates in bacterial community during operation of reactor for 8 and 12 hours. With the development of the bacterial community in the reactor the number of autotrophic nitrifies slightly increases, although, for a fact, nitrite and nitrate ions were detected only during inoculation of selective medium for the growth of autotrophs by the suspension after first dilution. In terms of numbers this corresponds to 10 cells per $1 \mathrm{ml}$. As a result it was shown that during ammonium deficiency and destruction of organic nitrogen autotrophic nitrifying bacteria was dying, their number was significantly decreasing. During the recycling of active sludge the number of autotrophs increases, but their nitrification activity is not significant and they do not affect the process of ammonium nitrogen oxidation.

The number of heterotrophic bacteria which present in 4 reactor zones is shown in table 1 .

Table 1.The number of heterotrophic bacteria in the samples from reactor zones.

\begin{tabular}{|c|c|c|c|c|}
\hline \multirow{2}{*}{$\begin{array}{c}\text { No. of } \\
\text { sample } \\
\text { (reactor's } \\
\text { zone) }\end{array}$} & \multicolumn{4}{|c|}{ Microbial count, cells/ml } \\
\cline { 2 - 5 } & Time of staying - 12 hours & \multicolumn{2}{c|}{ Time of staying - 8 hours } \\
\cline { 2 - 5 } & Bacteria & Mushrooms & Bacteria & Mushrooms \\
\hline 1 & $3.7^{*} 10^{7}$ & $4 * 10^{6}$ & $10^{*} 10^{7}$ & $0.3^{*} 10^{5}$ \\
\hline 2 & $3.2^{*} 10^{7}$ & Absent & $39.3^{*} 10^{7}$ & $1.0^{*} 10^{5}$ \\
\hline 3 & $4.2^{*} 10^{7}$ & Absent & $40.8^{*} 10^{7}$ & $1 * 10^{7}$ \\
\hline 4 & $2.7^{*} 10^{7}$ & Absent & $27.2^{*} 10^{7}$ & Absent \\
\hline
\end{tabular}


Analysis of the results in this table accurately reflects operating modes of the reactor. When reactor works for 12 hours the load on activated sludge in terms of organic pollutants and nitrogen ammonium is small, and hence the number of bacteria required for oxidization of these substances is small and their number is declining along with decrease of pollutants. Slight increase in micro-organisms number is observed only in the third zone of the reactor, but this is due to the fact that additional substrate (waste fluid) is fed into this zone. When reactor works for 8 hours then sharp increase in the number of microorganisms is noted in the aerated zone of the reactor, which suggests an improvement of their conditions, though the number of bacteria in the first zone is quite sufficient for the beginning of nitrification process. Decrease in the number of bacteria is observed along with reduction of pollution load in the fourth reactor's zone.

Results of nitrifies activity in the heterotrophic process showed that when reactor works for 8 hours the number of heterotrophic bacteria that are able to oxidize ammonium salts was 105 cells $/ \mathrm{ml}$, while the total number of micro-organisms in all reactor's zones was 2 times higher. When reactor is operated during fewer hours, the number of nitrifying bacteria-heterotrophs was 10 times higher in the second zone of the reactor and 20 times higher in the first zone. That nearly corresponds to the total number of heterotrophic bacteria in the sample. However, the number of heterotrophic nitrifying bacteria dropped to $103-104$ cells $/ \mathrm{ml}$ in the reactor zone 3, that 30-40 times less than the total number of bacteria in the sample. Nitrifying activity in the 4 reactor's zone is practically absent. If intake of nitrogen ammonium is limited then nitrifying activity of heterotrophic microorganisms is reduced to the level that is required for destruction of organic nitrogen and oxidation of formed ammonia nitrogen.

\section{Technology of biological treatment intensification for improvement of efficiency of removal of phosphorus and organic contaminants.}

For intensification of biological treatment in order to enhance the effectiveness of removal of phosphates from waste liquid there is another perspective method that does not require construction of special structures and that can be applied at the existing aeration tanks. The essence of the method is the application of reinforced feed material at facilities for biological treatment. Feed materials are mounted in the body of the aeration tank, that is previously reinforced with brand 3 steel wires. Reinforced feed material allows significantly improve the efficiency of the biological treatment regarding organic contaminants and phosphates. Mathematical description of treatment processes patterns allowed to calculate activation factor of the biological process -1.78 .

\section{Microbiological study of phosphate removal process}

$\mathrm{pH}$ inside of biofilm is acidic (presumably 4-5) due to activity of microorganisms. It creates favorable conditions for corrosion of metal which is located in feed material. Released iron ions promote active growth of bacteria, which increases removal efficiency regarding organic pollutants and forms specific biocoenosis that influences an increase of phosphate removal efficacy.

Microbiological studies of the live culture in active sludge and biofilms in light microscope showed that reinforced feed material activates life-sustaining activity of microorganisms in activated sludge and biofilms, as well as their species diversify. The results show a significant difference in composition and activity of microorganisms in sludge and biofilm of aeration tank with reinforced feed material and in control aeration 
tank without feed material reinforced with metal. In aeration tank (with reinforced feed material) there was significant increase in the number and variety of protozoa in active sludge (table 2).

Table 2.Composition of fixed microflora and free flowing activated sludge in the studied and control aeration tanks

\begin{tabular}{|c|c|c|}
\hline Name of microorganism & Studied aeration tank & $\begin{array}{c}\text { Control aeration } \\
\text { tank }\end{array}$ \\
\hline Chlorella sp. & Very large number & None detected \\
\hline Opercularia glomerata & Active & None detected \\
\hline Opercularia coartata & Active & None detected \\
\hline Aspidisca costata & Very active & Active \\
\hline $\begin{array}{c}\text { Aspidisca tuvrida } \\
\text { Vorticella sp. }\end{array}$ & Active & Active \\
\hline $\begin{array}{c}\text { Epistylis plicatilis } \\
\text { Rhabdomonas incurva } \\
\text { fresenius }\end{array}$ & No activity & None detected \\
\hline $\begin{array}{c}\text { Tokophrya mollis } \\
\text { Aelosoma hemprichi } \\
\text { Ehrenberg }\end{array}$ & Active & None detected \\
\hline $\begin{array}{c}\text { Rotifers } \\
\text { Philodina roseola }\end{array}$ & Very active & None detected \\
\hline $\begin{array}{c}\text { Rotifers } \\
\text { Callidina vorax }\end{array}$ & Active & Active \\
\hline $\begin{array}{c}\text { Rotifers } \\
\text { Cathypha luna }\end{array}$ & Active & No activity \\
\hline $\begin{array}{c}\text { Rotifers } \\
\text { Notommata ansata }\end{array}$ & & None detected \\
\hline
\end{tabular}

In the aeration tank with reinforced feed material sludge was heavily populated with different types of protozoa-rotifers, Opercularia SP., Aspidisca SP. etc., large number of microalgae Chlorella $s p$. Inhibitory effect on the development of Vorticella $s p$ was observed. It should be noted that all microorganisms except Vorticella sp were alive. Large number and diversity of rotifers in mixed sludge indicates the resistance to changes regarding pollution and biological system stability. Presence of Aelosoma Ehrenberg, Tokophrya mollis, Rhabdomonas incurva in active sludge suggests high quality and efficacy of wastewater treatment.

Steel wire contained in feed material, leads to intensive development of Chlorella sp . It is known that iron is needed for growth and sustaining of Chlorella life, that is why $0.2-0.8$ $\mathrm{mg} / \mathrm{l}$ of iron is commonly used for cultivation of Chlorella. Along with iron, phosphorus is required for Chlorella. Chlorella is sufficiently provided with phosphorus when its content is $10-100 \mathrm{mg} / \mathrm{l}$. Domestic scientists identified a correlation between the quantitative content of phosphorus in media and the increase in Chlorella cell number. Thus, the steel wire contained in feed material substantially affects biological processes occurring inside of biofilm and in suspended activated sludge, forming a specific biocoenosis that promotes 
intensification of biological treatment processes that allow to remove organic contaminants and phosphates.

\section{Conclusion}

Studies using microbiological plating proved that process of ammonia nitrogen oxidation in the reactor operated according to the scheme of single-sludge denitri-nitrification is carried out by nitrifying heterotrophic bacteria If supply of carbon and ammonia is insufficient these bacteria are able to secrete proteolytic enzymes to break down complex organic compounds - proteins, peptides, etc. and, thus, carry out deep treatment of waste water from various organic compounds and ammonia nitrogen. Among the observed options, preference is given to the experiment when sludge stayed in the reactor for 8 hours, because in this case the number of microorganisms is optimal for sewage water treatment and their ability to carry out nitrification in this mode of operation is the highest.

Based on microbiological studies we can conclude that reinforced feed material is beneficial to activated sludge and biofilm and explains intensifying effect on phosphate removal processes and removal of organic contaminants from waste water. This method of treatment can be recommended for intensification of biological wastewater treatment and increase of phosphate removal effect.

\section{References}

1. Elena Gogina, Nikolay Makisha, "Reconstruction of waste water treatment plants in Russia, approaches and solutions," Applied Mechanics and Materials, Vols. 361-363, pp. 628-631, DOI:10.4028/www.scientific.net/AMM.361-363.628 (2013)

2. Nikolay Makisha, Elena Gogina, "Floating feed in ammonium removal," Applied Mechanics and Materials, Vols. 361-363, pp. 632-635, DOI:10.4028/www.scientific.net/AMM.361-363.632 (2013)

3. O.A. Ruzhitskaya, E.S. Gogina, "Removal of phosphates from wastewater and intensify the biological wastewater treatment process from organic pollution," Advanced Materials Research, Vols. 919-921, pp. 2153-2156, DOI:10.4028/www.scientific.net/AMR.919-921.2153, (2014)

4. Elena Gogina, Nikolay Makisha, "Information technologies in view of complex solution of waste water problems," Applied Mechanics and Materials, Vols. 587589, pp. 636-639, DOI:10.4028/www.scientific.net/AMM.587-589.636, (2014)

5. Nikolay Makisha, Elena Gogina, "Methods of biological removal of nitrogen from waste water and ways to its intensification," Applied Mechanics and Materials, Vols. 587-589, pp. 644-647, DOI:10.4028/www.scientific.net/AMM.587-589.644, (2014)

6. O.A. Ruzhitskaya, E.S. Gogina, "Intensifying the processes of wastewater purification from phosphates and organic impurities," Advanced Materials Research, Vols. 919-921, pp. 2141-2144, DOI:10.4028/www.scientific.net/AMR.919-921.2141, (2014)

7. Elena Gogina, Igor Gulshin, "The single-sludge denitri-nitrification system in reconstruction of wastewater treatment plants in the Russian Federation," Applied Mechanics and Materials, Vols. 580-583, pp. 2367-2369, DOI:10.4028/www.scientific.net/AMM.580-583.2367, (2014)

8. Elena Gogina, Olga Ruzhitskaya, "One-sludge denitri-nitrification system application in reconstruction of biological treatment stations in Russian 
Federation," Applied Mechanics and Materials, Vols.725-726, pp.1325-1331, DOI:10.4028/www.scientific.net/AMM.725-726.1325, (2015)

9. Nikolay Makisha, Yury Voronov, Evgeny Poupyrev, Valery Volshanik, "Laboratory research of zeolite use for treatment of waste water of different origin," International Journal of Applied Engineering Research, Volume 10, Number 21, pp 41919-41922, (2015)

10. Nina Zaletova, Yury Voronov, Nikolay Makisha, "Conditions of advanced removal of phosphorus at wastewater treatment plants," International Journal of Applied Engineering Research, Volume 10, Number 21, pp 42454-42455, (2015)

11. Elena Gogina, Olga Yantsen, "Research of biofilter feed properties," International Journal of Applied Engineering Research, Volume 10, Number 24, pp 4407044074, (2015)

12. Nikolay Makisha, Vladimir Scherbakov, Alexander Smirnov, Elena Scherbina, "Percolation units for waste water treatment," International Journal of Applied Engineering Research, Volume 10, Number 24, pp 44347-44349, (2015)

13. Vladimir Scherbakov, Elena Gogina, Tatiana Schukina, Nadezhda Kuznetsova, Nikolay Makisha, Evgeny Poupyrev, "Calculation of biogas facilities for recycling of organic sewage sludge of breeding factories," International Journal of Applied Engineering Research, Volume 10, Number 24, pp 44353-44356, (2015)

14. Igor Gulshin, Anisa Kuzina, "Adaptation of nitrifying activated sludge to simultaneous nitrification and denitrification in the lab-scale oxidation ditch," International Journal of Applied Engineering Research, Volume 10, Number 21, pp 42618-42623, (2015)

15. Ruzhitskaya Olga, Yantsen Olga, "Wastewater treatment to remove phosphate and organic pollutants", International Journal of Applied Engineering Research, Volume 11, Number 5, pp 3496-3498, (2016)

16. Hwang Jae-Hoon, Church Jared, Lee Seung-Jin, Park Jungsu, and Lee Woo Hyoung. Environmental Engineering Science. November 2016, 33(11): 882-897. doi:10.1089/ees.2016.0132. (2016)

17. Yixuan Yang, Fei Tang, Xiaoling Su, Hua Yin, Fei Ge, «Identification and evaluation of a dominant alga from municipal wastewater in removal of nutrients», Water Sci. and Technol., Published December 2016, 74 (11) 27272735; DOI: 10.2166/wst.2016.437 (2016) 